OPEN ACCESS

Edited by:

Heng Zhang,

Chinese Academy of Sciences

(CAS), China

Reviewed by:

Łukasz Wojtyla,

Adam Mickiewicz University, Poland Nadia Bazihizina

University of Florence, Italy

${ }^{*}$ Correspondence: Jianrong Guo gjr2005@126.com

Baoshan Wang

bswang@sdnu.edu.cn

Specialty section: This article was submitted to

Plant Abiotic Stress, a section of the journal

Frontiers in Plant Science

Received: 03 September 2020 Accepted: 26 November 2020

Published: 14 December 2020

Citation:

Guo J, Liu L, Du M, Tian H and

Wang B (2020) Cation and Zn Accumulation in Brown Seeds of the Euhalophyte Suaeda salsa Improves Germination Under Saline Conditions.

Front. Plant Sci. 11:602427. doi: $10.3389 / f p l s .2020 .602427$

\section{Cation and $\mathrm{Zn}$ Accumulation in Brown Seeds of the Euhalophyte Suaeda salsa Improves Germination Under Saline Conditions}

\author{
Jianrong Guo ${ }^{1 *}$, Lili Liu ${ }^{1}$, Ming Du ${ }^{1}$, Huaying Tian ${ }^{2}$ and Baoshan Wang ${ }^{1 *}$ \\ ${ }^{1}$ Shandong Provincial Key Laboratory of Plant Stress, College of Life Science, Shandong Normal University, Ji'nan, China, \\ ${ }^{2}$ College of Forestry Engineering, Shandong Agriculture and Engineering University, Ji'nan, China
}

Salinity inhibits plant growth due to salt ion accumulation in plant cells and reduced absorption of other nutrients such as metal ions; however halophyte plants have evolved mechanisms to survive and thrive in high-salt conditions. The euhalophyte Suaeda salsa generates dimorphic seeds (black and brown), which show marked differences in germination and seedling growth under high-salt conditions. However, it is unclear whether their ionic status differs. Here, to provide insight on the role of ions in salt tolerance, we used inductively coupled plasma mass spectrometry to measure the ion contents in the dimorphic seeds from S. salsa plants treated with or without $\mathrm{NaCl}$. We measured the macroelements $\mathrm{Na}, \mathrm{K}, \mathrm{Mg}$, and $\mathrm{Ca}$, and the microelements $\mathrm{Mn}, \mathrm{Fe}, \mathrm{Zn}$, $\mathrm{Cu}$, and $\mathrm{Mo}$. NaCl-treated S. salsa plants produced seeds with significantly reduced metallic element contents and significantly increased $\mathrm{Na}^{+}$contents. The brown seeds of S. salsa plants treated with 0 and $200 \mathrm{mM} \mathrm{NaCl}$ had much higher contents of $\mathrm{K}^{+}, \mathrm{Ca}^{2+}$, and $\mathrm{Fe}^{2+}$ compared with the black seeds. However, the S. salsa seeds (both black and brown) from $\mathrm{NaCl}$-treated plants were significantly larger, and had higher germination rate and higher seedling salt tolerance compared with seeds from plants not treated with $\mathrm{NaCl}$. Interestingly, we measured significantly higher $\mathrm{Zn}^{2+}$ contents in the brown seeds from plants treated with $\mathrm{NaCl}$ compared with the black seeds. This suggests that the high contents of $\mathrm{Zn}^{2+}$ and other cations affected seed development and salt tolerance during germination under high-salt conditions. These observations provide insight into the mechanisms of salt tolerance in this halophyte and inform efforts to increase salt tolerance in salt-sensitive species.

Keywords: cation content, dimorphic seed, $\mathrm{NaCl}$ treatment, salinity tolerance, Suaeda salsa L.

\section{INTRODUCTION}

Excess salt has emerged as one of the main causes decreasing crop yields in saline, arid, and semi-arid areas. It causes injury to plants due to osmotic stress, ion toxicity, and nutrient deficits (Munns and Tester, 2008). High salinity can disrupt the absorption of mineral elements by plants, resulting in nutrient imbalance, inhibited growth and development, and redistribution of biomass (Hu et al., 2007). Plants have evolved various strategies to reduce the damage caused by saline environments, one of which is to accumulate large quantities of inorganic ions in the vacuole for 
osmotic adjustment and avoidance of ion toxicity (Wang et al., 2004; Han et al., 2005; Qiu et al., 2007; Munns and Tester, 2008; Yang et al., 2010). Previous studies of the distribution of mineral nutrient elements in plants under salt stress mainly focused on mineral absorption and transport in roots (Ebrahimi and Bhatla, 2012). Therefore, little is known about mineral nutrient accumulation in reproductive organs under salt stress, especially in seeds.

Ionomics is the analysis of all the ions in an organism, including the metals and non-metallic elements that are the inorganic components of biological systems (Lahner et al., 2003; Salt et al., 2008; Ding et al., 2010). Ionomics can be used to examine changes in the elemental composition of organisms associated with different stages of development, different growth conditions, or different genotypes. Inductively coupled plasma mass spectrometry (ICP-MS) and other highthroughput technologies for elemental determination provide a new opportunity for investigating the relationship between ion content and plant processes, including gene function, gene networks, growth and development, and physiological processes (Lahner et al., 2003; Salt et al., 2008).

Ion content in plants is regulated by various processes, such as ion uptake, transport, and accumulation, and can be used to evaluate the physiological status of a plant. The use and redistribution of ions in plant cells is regulated by the plant's growth and development, including physiological and metabolic processes. This regulation is reflected in the changes in the ionic composition of the plant that accompany its growth and development. Thus, changes in the ion composition of plant cells reflect the specific growth and environmental state of plants.

Salinity leads to changes in the ion content of specific tissues or specific developmental stages of plants. For example, in Arabidopsis thaliana, plants subjected to salt stress had an altered $\mathrm{Ca}^{2+}$ contents when compared with control plants (Kudla et al., 2010; Ma et al., 2019; Yang et al., 2019). Additionally, the content of other ions, such as $\mathrm{K}^{+}$, and $\mathrm{Mg}^{2+}$, were decreased in plants under salinity stress conditions (Hafsi et al., 2017; Kausar and Gull, 2019). In plants, normal development, especially seed germination, is inseparable from the absorption and distribution of mineral elements.

The seed is the most important storage organ of plants and plays a central role in plant life cycles. Seeds formed under adverse environmental conditions can be of inferior quality, severely affecting the reproductive capacity and crop yield of the plants grown from them (Kranner et al., 2010; Song et al., 2016). In some cases, an individual plant produces two kinds of seeds, a phenomenon known as seed dimorphism. Dimorphic seeds usually differ in color, size, and morphology, as well as in dormancy and germination characteristics (Imbert, 2002). Seed dimorphism is prevalent in halophytes; it may be related to the spatial and temporal variability in the salinity halophytes encounter (Ungar, 1995; Song et al., 2017) and it is an important strategy for halophytes to adapt to different environments. Plants generated from seeds of different growth conditions may display differences in biomass, photosynthesis, and reproductive capacity (Talavera et al., 2010; Guo et al., 2020a). However, it is not known whether the mineral contents differ in different types of seeds or in seeds produced in different growth environments.

Suaeda salsa L. is an herbaceous plant widely distributed in the saline areas of northern China. This plant adapts to saline habitats by accumulating salt ions in the vacuole and regulating cellular osmotic potential (Wang et al., 2004; Han et al., 2005; Qiu et al., 2007; Qi et al., 2009; Yang et al., 2010; Mori et al., 2011), as well as by having a highly efficient antioxidant system (Pang et al., 2005, 2011; Wu et al., 2012). S. salsa also displays seed dimorphism; a single plant can produce black and brown seeds (Song et al., 2008; Song and Wang, 2015). Additionally, the organic storage materials and viability of $S$. salsa seeds are affected by the concentration of $\mathrm{NaCl}$ in the growth medium (Guo et al., 2015, 2018). Whether the growth environment also affects the mineral content of $S$. salsa seeds is unknown.

The main aim of the present study was to investigate the cation content of the black and brown seeds produced by $S$. salsa plants grown on different $\mathrm{NaCl}$ concentrations, and to determine the relationship between seed mineral content and germination under saline conditions. S. salsa plants were subjected to 0 and $200 \mathrm{mM} \mathrm{NaCl}$, from seed sowing to seed harvesting, and their seeds were individually hand-harvested. We used ICPMS to analyze the cation contents of the seeds, including the macroelements $\mathrm{Na}, \mathrm{K}, \mathrm{Mg}$, and $\mathrm{Ca}$, and the microelements $\mathrm{Mn}$, $\mathrm{Fe}, \mathrm{Zn}, \mathrm{Cu}$, and Mo. Understanding the relationship between seed mineral content and salt tolerance may help to identify the patterns of mineral accumulation and distribution that influence the ability of halophytes to establish populations under saline conditions.

\section{MATERIALS AND METHODS}

\section{Plant Materials}

Suaeda salsa seeds were collected from the saline habitats of Shandong province and cultured as described in Guo et al. (2015), and first-, second-, and third-generation S. salsa seeds grown on 0 and $200 \mathrm{mM} \mathrm{NaCl}$ were obtained. The seed size of the three generations was measured using a micrometer. The third generation of $S$. salsa seeds were collected and used for ionomics analysis.

\section{Germination of Seeds at Different $\mathrm{NaCl}$ Concentrations}

To investigate the seed quality and salt tolerance of the seeds from different conditions, the three generations of seeds harvested from plants grown under control $(0 \mathrm{mM} \mathrm{NaCl})$ and $200 \mathrm{mM} \mathrm{NaCl}$ were germinated at 0,200 , or $400 \mathrm{mM} \mathrm{NaCl}$ as described in our previous study (Guo et al., 2018).

\section{Ion Extraction and Analysis}

The two types of seeds (black and brown), obtained from plants grown on 0 and $200 \mathrm{mM} \mathrm{NaCl}$, were washed using ultrapure water (Milli-Q Reference, Millipore, USA) three times and dried for $36 \mathrm{~h}$ in an oven at $50^{\circ} \mathrm{C}$. For each condition, a $15 \mathrm{mg}$ subsample of seeds was weighed and put in a plastic tube (17 * $100 \mathrm{~mm}, 14 \mathrm{~mL}$, Falcon). Next, $1 \mathrm{~mL}$ of $\mathrm{HNO}_{3}$ (68.0\%) was added to each tube and the samples were digested for about $48 \mathrm{~h}$. 
Then ultrapure water was added to each tube to a final volume of $14 \mathrm{~mL}$. The elements were measured using ICP-MS (ELAN DRC-e, PerkinElmer, USA).

The relevant cation content was calculated according to the following formula:

The cation content in the sample ( $\mu \mathrm{mol} / \mathrm{g}$ dry mass $)=\frac{C^{*} V}{M^{*} W}$ $\mathrm{C}$ is the ion content measured by ICP-MS $(\mu \mathrm{g} / \mathrm{L})$; V is the volume of the total liquid extract $(\mathrm{L}) ; \mathrm{M}$ is a relative atomic mass of the ion $(\mathrm{g} / \mathrm{mol})$; $\mathrm{W}$ is the dry sample weight $(\mathrm{g})$.

Total ion content $(\mu \mathrm{mol} / \mathrm{g}$ dry mass $)=$ sum of various ionic contents.

Contribution of an ion to total ion content $(\%)=$ the ion content $(\mu \mathrm{mol} / \mathrm{g}$ dry mass)/the total ion content $(\mu \mathrm{mol} / \mathrm{g}$ dry mass).

\section{Instrument Operating Parameters}

Inductively coupled plasma parameters: power $1100 \mathrm{~W}$, cooling gas flow (Ar) $15.0 \mathrm{~L} / \mathrm{min}$, auxiliary air flow (Ar) $1.3 \mathrm{~L} / \mathrm{min}$, carrier gas flow (Ar) $0.94 \mathrm{~L} / \mathrm{min}$.

Mass spectrometer parameters: analysis room vacuum, $6 \times 10^{-7}$ Torr, measurement parameters for the resolution
(10\% peak height): $0.7 \mathrm{amu}$, dwell time $50 \mathrm{~ms}$, repeat three times, measuring point 1, number of cycles 20; Quality scanning, sample analysis event $28 \mathrm{~s}$, sample extraction $1 \mathrm{~mL} / \mathrm{min}$.

\section{Ionic Analysis of S. salsa Leaves, Flowers, and Seeds}

To determine the relationship of ion accumulation from the maternal plants (leaves and flowers) to the seeds of $S$. salsa treated with $\mathrm{NaCl}$, the leaves and the corresponding flowers and seeds were collected to determine the $\mathrm{Na}^{+}, \mathrm{K}^{+}$concentrations. The $S$. salsa seedlings were cultured with rinsed river sand and were irrigated with control (without $\mathrm{NaCl}$ ) and $\mathrm{NaCl}$ $(200 \mathrm{mM} \mathrm{NaCl})$ twice a day (one is in the morning and the other in the late afternoon), which were same as the mother plants (seeds from control plants were treated with control, and seeds from $\mathrm{NaCl}$-treated plants were treated with $\mathrm{NaCl}$ ), and the treatment were conducted from seeds were sown till seed maturity. The preparation and determination of $\mathrm{Na}^{+}, \mathrm{K}^{+}$content were same as the previous description (Guo et al., 2018).
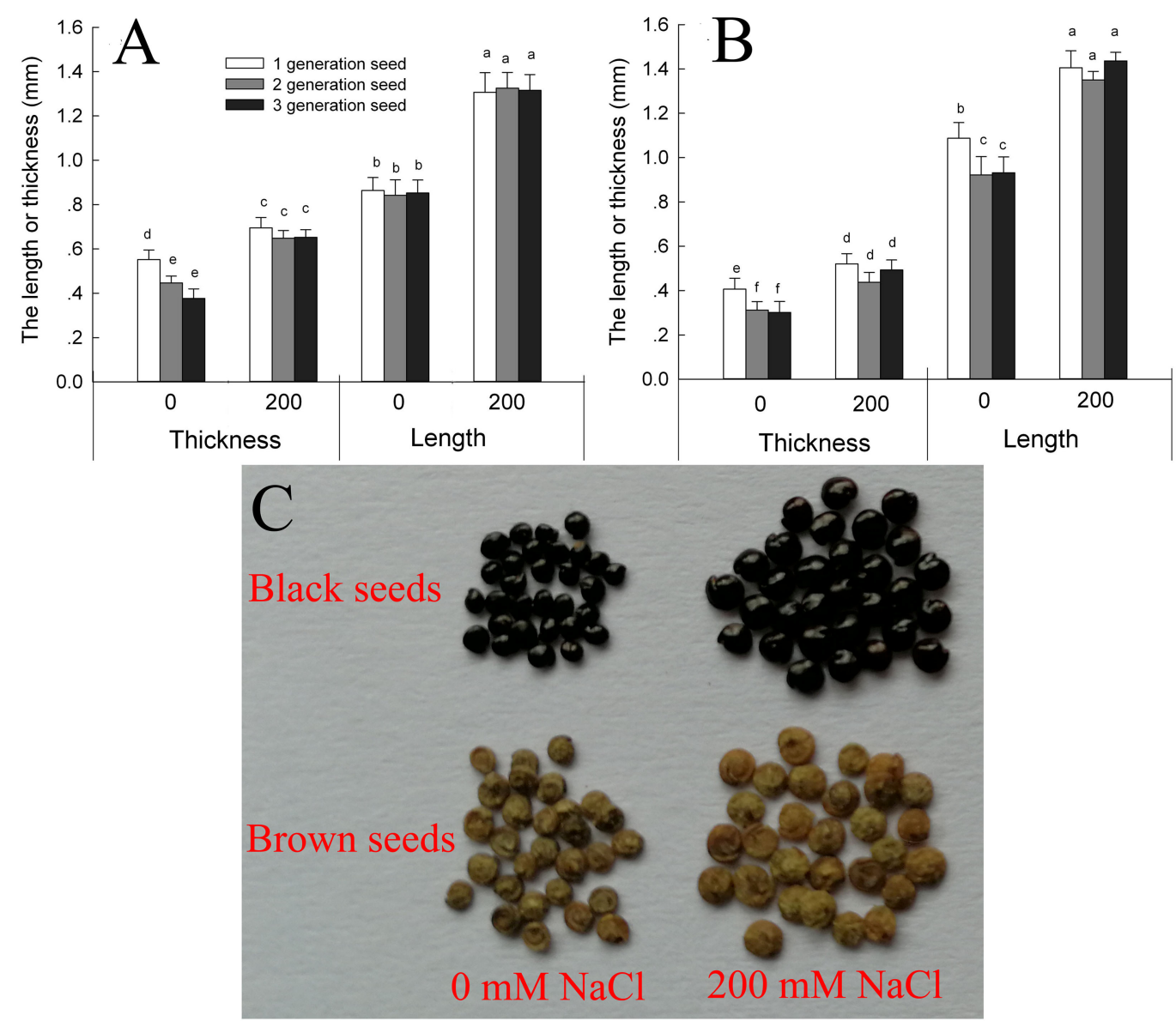

FIGURE 1 | Size of black (A) and brown (B) seeds of Suaeda salsa from mother plants of different generations grown in 0 or $200 \mathrm{mM}$ NaCl, and images of the third-generation seed $(\mathbf{C})$. Values are presented as means $\pm \mathrm{SD}(n=100)$. Different lower-case letters in the figure indicate significant difference at level of $P<0.05$. 


\section{Statistical Analysis}

The experimental data are means \pm SD of three replicates. The data were analyzed by SPSS software (version 17) and based on the ANOVA (one-way) method. Different letters in the figures and tables indicate a significant difference among the mean values $(P<0.05)$ by Duncan's test.

\section{RESULTS}

\section{Characteristics of Seeds From S. salsa Plants Grown on 0 and $200 \mathrm{mM} \mathrm{NaCl}$}

Suaeda salsa plants produce brown seeds and black seeds. We found that the brown seeds were significantly longer and narrower than the black seeds when the seeds were obtained from plants grown under the same conditions (Figures 1A-C). Seed development was promoted by growth on $200 \mathrm{mM} \mathrm{NaCl}$, and seeds produced by the salt-treated plants were significantly longer and wider than those produced by control plants. For third-generation seeds, the black seeds of salt-grown plants were $152.1 \%$ longer and $125.6 \%$ wider than those of control plants, and the brown seeds were $128.7 \%$ longer and $127.9 \%$ wider. The main factor that affecting the seed size was seed source (from the maternal plant that grown with 0 or $200 \mathrm{mM} \mathrm{NaCl}$ ) and seed type (black or brown seed) (Supplementary Table 1).

\section{Brown S. salsa Seeds Germinate at a Higher Rate Than Black Seeds}

To determine whether brown and black seeds differ in their germination rate and salt tolerance, seeds were harvested from plants that had been grown for three generations on 0 or $200 \mathrm{mM} \mathrm{NaCl}$ and then germinated on 0,200 , or $400 \mathrm{mM} \mathrm{NaCl}$ (Figure 2). Generally, the germination rate decreased as $\mathrm{NaCl}$ concentration increased for both black and brown seeds. At each concentration of $\mathrm{NaCl}$ in the germination test, brown seeds had a significantly higher germination rate than black seeds, no matter whether the seeds came from 0 or $200 \mathrm{mM} \mathrm{NaCl}$-treated parents. Seeds harvested from parent plants treated with $200 \mathrm{mM} \mathrm{NaCl}$ displayed better germination relative to seeds from control plants (Figure 2). Interestingly, we observed a significant reduction in germination rate for black seeds harvested from plants treated with $0 \mathrm{mM} \mathrm{NaCl}$ in the second and third generations, but not seeds harvested from plants treated with $200 \mathrm{mM} \mathrm{NaCl}$ (Figure 2A). No significant reduction in germination rate was observed for both seeds from $\mathrm{NaCl}$-treated plants in the first, second, and third generations (Figure 2B). The main factor that affecting the seed germinate rate was seed source (from the maternal plant that grown with 0 or $200 \mathrm{mM} \mathrm{NaCl}$ ) and seed type (black or brown seed) (Supplementary Table 1).

\section{Cation Contents of Seeds From S. salsa Plants Treated With 0 and $200 \mathrm{mM} \mathrm{NaCl}$} Total Macroelements

Compared to the first generation, the seed size of the control plants was reduced in the second and third generations, and seeds from the third generation of the 0 and $200 \mathrm{mM} \mathrm{NaCl}$ treatments were selected for analysis of cation content. Brown seeds had more metal ions than black seeds, under both 0 and $200 \mathrm{mM} \mathrm{NaCl}$ conditions. The total ion content of the brown seeds was 1.68 fold and 1.49-fold higher than that of the black seeds harvested from plants cultured with 0 and $200 \mathrm{mM} \mathrm{NaCl}$, respectively. Furthermore, the total cation contents of both types of seeds were lower if they came from salt-treated plants than if they came from control plants; the cation contents were 70.3 and $79.1 \%$ of control for brown seeds and black seeds, respectively.

\section{$\mathrm{Na}^{+}$Content}

$\mathrm{Na}^{+}$is the main cation present in saline environments. High concentrations of salt in the growth environment can compete with other nutrients and prevent the absorption of some essential elements, such as $\mathrm{K}$ and Fe. By contrast, $\mathrm{Na}$ is beneficial for some

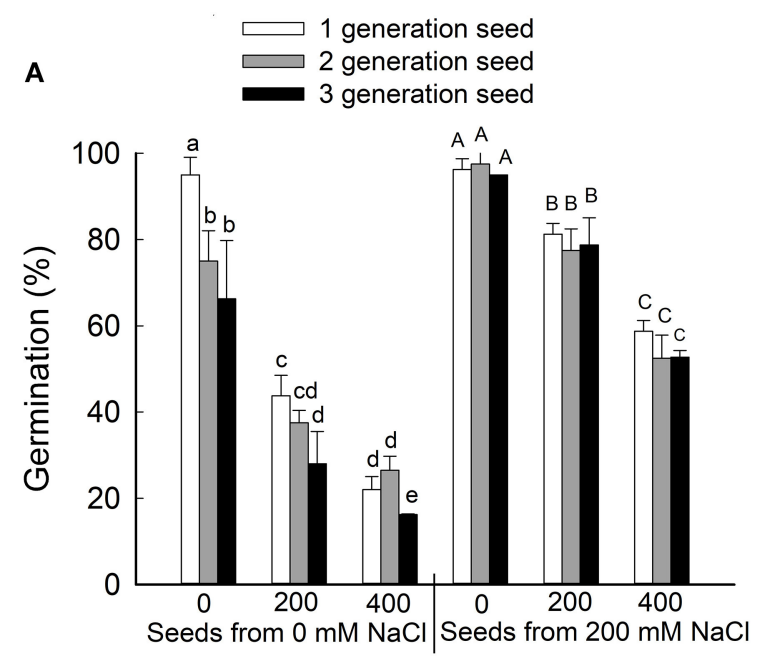

B

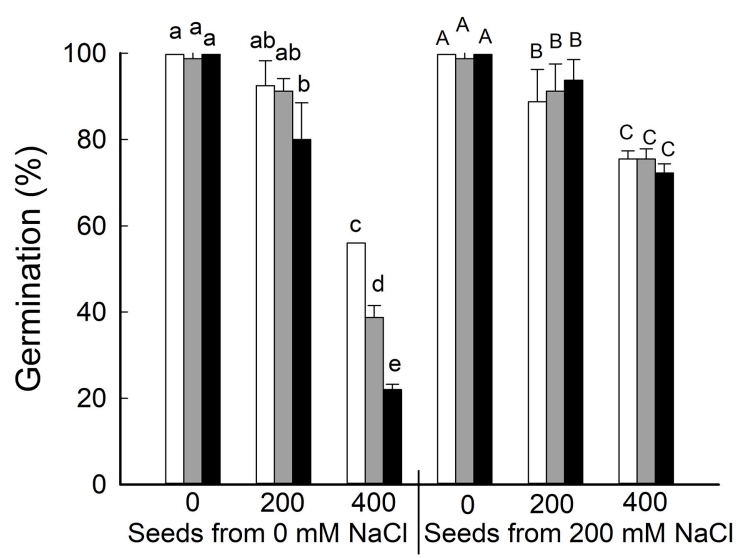

FIGURE 2 | Germination percentages (\%) of the black (A) and brown (B) seeds of Suaeda salsa from mother plants of different generations grown on 0 or $200 \mathrm{mM}$ $\mathrm{NaCl}$. Values are presented as means $\pm \mathrm{SD}(n=4)$. Different lower-case letters in the figure indicate significant difference at level of $P<0.05$. 
TABLE 1 | Macroelement contents in the black and brown seeds harvested from mother Suaeda salsa plants of the third generation grown on 0 or 200 mM NaCl.

\begin{tabular}{|c|c|c|c|c|}
\hline \multirow[t]{2}{*}{$\mathrm{NaCl}$ concentration (mM) } & \multicolumn{2}{|c|}{ Black seeds } & \multicolumn{2}{|c|}{ Brown seeds } \\
\hline & 0 & 200 & 0 & 200 \\
\hline $\mathrm{Na}$ & $72.03 \pm 0.20 c$ & $724.35 \pm 99.42 a$ & $147.10 \pm 17.24 b$ & $685.79 \pm 77.10 a$ \\
\hline K & $521.71 \pm 35.89 b$ & $191.57 \pm 17.59 d$ & $859.14 \pm 38.29 a$ & $379.31 \pm 15.55 c$ \\
\hline $\mathrm{Ca}$ & $46.23 \pm 1.52 b$ & $12.25 \pm 1.16 d$ & $98.91 \pm 4.96 \mathrm{a}$ & $29.30 \pm 1.30 c$ \\
\hline $\mathrm{Mg}$ & $1160.83 \pm 68.05 b$ & $495.83 \pm 36.94 d$ & $1919.16 \pm 75.83 a$ & $1030.55 \pm 70.00 c$ \\
\hline Total & 1800.80 & 1424.01 & 3024.33 & 2124.97 \\
\hline
\end{tabular}

Cation content, $\mu$ moles/g dry mass. Values are presented as means $\pm S D(n=3)$.

Different lower-case letters in the same row indicate significant difference between the seed types at level of $P<0.05$.

halophytes, helping these plants adjust their osmotic potentials when they grow in saline environments. For instance, plants in the genus Suaeda absorb large amounts of $\mathrm{Na}^{+}$in saline environments and sequester it in vacuoles to reduce water potential and prevent ion toxicity (Flowers and Yeo, 1986).

Suaeda salsa seeds produced by $\mathrm{NaCl}$-treated plants had significantly increased $\mathrm{Na}^{+}$contents: $\mathrm{Na}^{+}$was 4.6 times higher in brown seeds and 10.1 times higher in black seeds than in the corresponding seed types from control plants. In addition, in seeds from salt-treated plants, $\mathrm{Na}^{+}$ions were a significantly higher percentage of the total ions (brown seeds, 32.2\%; black seeds, $50.8 \%$ ) than they were in seeds from control plants (brown seeds, 4.8\%; black seeds, 3.9\%) (Table 1). For the control plants, brown seeds accumulated 2.0 times more $\mathrm{Na}^{+}$than the black seeds. By contrast, there was no significant difference in the $\mathrm{Na}^{+}$contents of the two types of seeds from plants treated with $200 \mathrm{mM} \mathrm{NaCl}$ (Table 1).

\section{$\mathrm{K}^{+}$Content}

$\mathrm{K}^{+}$is necessary for plant growth and development and is an important ion for osmotic adjustment. Under salt stress, plants can increase their salt tolerance by maintaining the cytoplasmic $\mathrm{K}^{+}$concentration above the minimum value that is necessary to maintain normal growth under stress. For both 0 and $200 \mathrm{mM}$ $\mathrm{NaCl}$ treatments, the $\mathrm{K}^{+}$content of the black seeds was markedly lower than that of the brown seeds: the black seeds had 60.7 and $50.5 \%$ the $\mathrm{K}^{+}$of brown seeds at 0 and $200 \mathrm{mM} \mathrm{NaCl}$, respectively. The $\mathrm{K}^{+}$content in both types of seeds was significantly reduced when the parent plants were treated with $200 \mathrm{mM} \mathrm{NaCl}: 44.1 \%$ of control for brown seeds and $36.7 \%$ of control for black seeds (Table 1). High $\mathrm{Na}^{+}$competitively inhibits $\mathrm{K}^{+}$uptake, which may be one reason why seeds from $\mathrm{NaCl}$-treated plants had lower $\mathrm{K}^{+}$contents than seeds from control plants.

\section{$\mathrm{Ca}^{2+}$ Content}

$\mathrm{Ca}^{2+}$ plays a vital role in growth and salt resistance in plants. As an effective membrane protectant, $\mathrm{Ca}^{2+}$ improves the stability of cell walls, cell membranes, and membrane-bound proteins. In the present study, $\mathrm{NaCl}$ treatment of $S$. salsa plants decreased the $\mathrm{Ca}^{2+}$ content of their seeds, by $70.4 \%$ for brown seeds and $73.5 \%$ for black seeds relative to the corresponding seed types from control plants. Brown seeds accumulated more $\mathrm{Ca}^{2+}$ than black seeds, regardless of the growth conditions: 1.13-fold more in control plants and 1.39 -fold more in $200 \mathrm{mM} \mathrm{NaCl}$ treated plants.

\section{$\mathrm{Mg}^{2+}$ Content}

As a component of chlorophyll and an enzyme activator, $\mathrm{Mg}^{2+}$ plays an important role in plant development and salt tolerance. For example, $\mathrm{Mg}^{2+}$ participates in lipid and phosphorus metabolism. In the present study, more $\mathrm{Mg}^{2+}$ accumulated in the brown seeds than in the black seeds from both salt-treated and control plants. Seeds from plants treated with $200 \mathrm{mM} \mathrm{NaCl}$ had significantly less $\mathrm{Mg}^{2+}$ than the control seeds: $46.3 \%$ less in brown seeds and $57.3 \%$ less in black seeds (Table $\mathbf{1}$ ).

\section{Total Microelements}

Compared with the seeds harvested from control $(0 \mathrm{mM} \mathrm{NaCl})$ S. salsa plants, seeds harvested from treated $(200 \mathrm{mM} \mathrm{NaCl})$ plants had a reduced total microelement content in both the brown seeds (73.4\% of control) and the black seeds $(49.9 \%$ of control) (Table 2). Under both growth conditions, the brown seeds accumulated more microelements than the black seeds, especially $\mathrm{Zn}^{2+}$. Total microelement content in the brown seeds was 1.31- and 1.93-fold that of the black seeds from control and treated plants, respectively.

\section{$\mathrm{Fe}^{2+}$ Content}

As one of the essential microelements for plant growth, $\mathrm{Fe}^{2+}$ participates in a variety of important metabolic activities in plants. To ensure the normal growth and development of plant, a certain amount of $\mathrm{Fe}^{2+}$ in cells should be maintained. $\mathrm{Fe}^{2+}$ content in black seeds was significantly lower than in brown seeds; black seeds had 63.3 and $40.5 \%$ of the amount of $\mathrm{Fe}^{2+}$ in brown seeds for control and $200 \mathrm{mM} \mathrm{NaCl}$-treated plants, respectively. Furthermore, the $\mathrm{Fe}^{2+}$ content was reduced by $\mathrm{NaCl}$ treatment, both in brown seeds (34.7\% decrease) and black seeds (58.2\% decrease), relative to seeds from control plants (Table 2).

\section{$\mathrm{Mn}^{2+}$ Content}

Manganese is an essential plant micronutrient involved in photosynthesis, nitrogen transformations, redox reactions, and many other enzyme activities, as well as promoting chlorophyll biosynthesis and carbohydrate transport. $\mathrm{NaCl}$ treatment significantly reduced the $\mathrm{Mn}^{2+}$ content in both types of seeds in S. salsa. Although there was no significant difference in $\mathrm{Mn}^{2+}$ 
TABLE 2 | Microelement contents in the black and brown seeds harvested from mother Suaeda salsa plants of the third generation grown on 0 or 200 mM NaCl.

\begin{tabular}{|c|c|c|c|c|}
\hline \multirow[t]{2}{*}{$\mathrm{NaCl}$ concentration $(\mathrm{mM})$} & \multicolumn{2}{|c|}{ Black seeds } & \multicolumn{2}{|c|}{ Brown seeds } \\
\hline & 0 & 200 & 0 & 200 \\
\hline $\mathrm{Fe}$ & $5035.09 \pm 122.81 b$ & $2104.09 \pm 106.43 c$ & $7957.89 \pm 409.36 a$ & $5198.83 \pm 530.99 b$ \\
\hline $\mathrm{Mn}$ & $2927.27 \pm 127.27 a$ & $1624.85 \pm 123.03 c$ & $2418.18 \pm 42.42 b$ & $1849.69 \pm 186.67 c$ \\
\hline $\mathrm{Cu}$ & $130.44 \pm 4.52 b$ & $72.07 \pm 5.55 c$ & $183.70 \pm 10.37 a$ & $138.66 \pm 13.93 b$ \\
\hline $\mathrm{Zn}$ & $859.79 \pm 48.08 c$ & $661.82 \pm 74.95 d$ & $1181.51 \pm 21.92 b$ & $1429.69 \pm 83.43 a$ \\
\hline Mo & $5.52 \pm 0.22 c$ & $7.69 \pm 0.92 b$ & $9.54 \pm 0.36 a$ & $10.19 \pm 0.095 a$ \\
\hline Total & 8958.13 & 4470.52 & 11750.84 & 8627.08 \\
\hline
\end{tabular}

Cation content, nmoles/g dry mass. Values are presented as means $\pm S D(n=3)$.

Different lower-case letters in the same row indicate significant difference between the seed types at level of $P<0.05$.

content between the two types of seeds from the treated plants, black seeds accumulated 1.21-times more $\mathrm{Mn}^{2+}$ than brown seeds from the control plants (Table 2).

\section{$\mathrm{Cu}^{2+}$ Content}

The trends for $\mathrm{Cu}^{2+}$ accumulation were similar to those for $\mathrm{Mg}^{2+}$. For both control and treated plants, the brown seeds accumulated more $\mathrm{Cu}^{2+}$ than the black ones. Compared to the control, $\mathrm{NaCl}$ treatment led to significantly reduced $\mathrm{Cu}^{2+}$ content in both types of seeds (Table 2).

\section{$\mathrm{Zn}^{2+}$ Content}

Microelement deficiency could be considered to be one of the main symptoms of salt poisoning in plants. For the halophyte $S$. salsa, brown seeds had more $\mathrm{Zn}^{2+}$ than black seeds, regardless of the growth conditions ( $0 \mathrm{mM}$ vs. $200 \mathrm{mM} \mathrm{NaCl}$ ) of the parent plants. Unexpectedly, the $\mathrm{Zn}^{2+}$ content of brown seeds from plants cultured in $200 \mathrm{mM} \mathrm{NaCl}$ was significantly higher (1.21 times) than that of brown seeds from plants cultured in $0 \mathrm{mM}$ $\mathrm{NaCl}$. The higher $\mathrm{Zn}^{2+}$ content in the brown seeds might be associated with their higher salt tolerance (Table 2).

\section{$\mathrm{Mo}^{2+}$ Content}

For both control and salt-treated plants, the brown seeds had a significantly higher $\mathrm{Mo}^{2+}$ content than the black seeds. Surprisingly, $\mathrm{NaCl}$ treatment significantly enhanced the $\mathrm{Mo}^{2+}$ content in black seeds to 1.39 times the amount in the control black seeds. For the brown seeds there was no significant difference in $\mathrm{Mo}^{2+}$ content between the control and $200 \mathrm{mM}$ $\mathrm{NaCl}$ treatment.

\section{Ionic Analysis of S. salsa Leaves, Flowers, and Seeds}

To investigate the causes of the differences in ion content between the $S$. salsa seeds grown under different concentrations of $\mathrm{NaCl}$, we analyzed the $\mathrm{Na}^{+}$and $\mathrm{K}^{+}$contents of leaves, flowers, and seeds of control and $\mathrm{NaCl}$-treated plants.

$\mathrm{Na}^{+}$Contents of S. salsa Leaves, Flowers, and Seeds The $\mathrm{Na}^{+}$contents of leaves, flowers, brown seeds, and black seeds were significantly increased under the $200 \mathrm{mM} \mathrm{NaCl}$ condition, to $5.3,5.2,4.7$, and 10.1 times the $\mathrm{Na}^{+}$contents of the control,

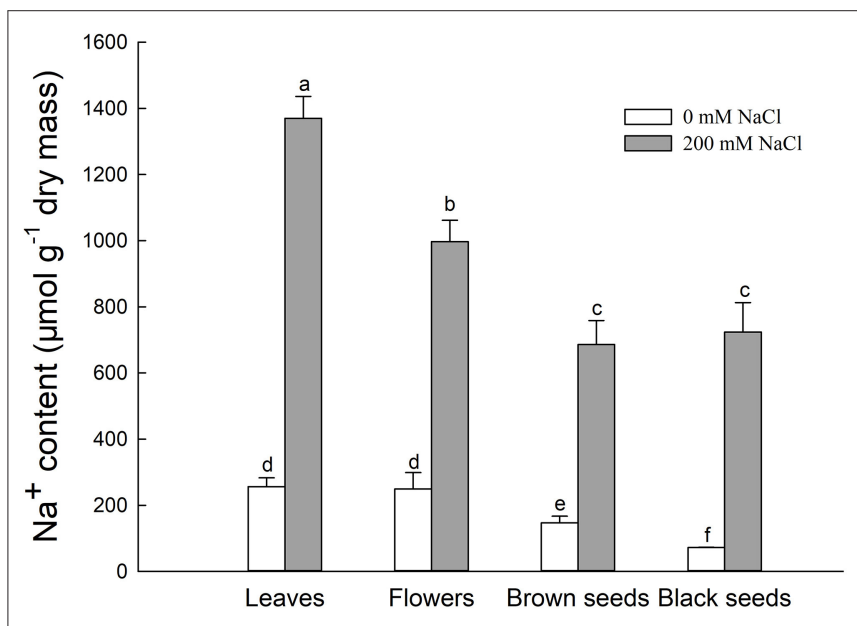

FIGURE 3 | $\mathrm{Na}^{+}$content in leaves, flowers, and seeds of second-generation mother Suaeda salsa plants grown on 0 or $200 \mathrm{mM} \mathrm{NaCl}$. Values are presented as means $\pm \mathrm{SD}(n=4)$. Different lower-case letters in the figure indicate significant difference at level of $P<0.05$.

respectively (Figure 3). For NaCl-treated plants, the leaves had the highest $\mathrm{Na}^{+}$content, followed by the flowers. The $\mathrm{Na}^{+}$ contents of the seeds were significantly lower than that of the flowers; the amounts in brown and black seeds were 68.7 and $72.5 \%$ the amount in the flowers, respectively. Thus, the $\mathrm{Na}^{+}$ content decreased gradually from leaf to flower to seed in the salt-treated plants. For the control plants, there was no significant difference in $\mathrm{Na}^{+}$content between the leaves and the flowers, and the $\mathrm{Na}^{+}$content was significantly lower in the seeds; the $\mathrm{Na}^{+}$ contents of brown seeds and black seeds were 58.8 and $28.8 \%$ that of the flowers, respectively (Figure 3).

\section{$\mathrm{K}^{+}$Contents of S. salsa Leaves, Flowers, and Seeds}

Generally, $\mathrm{K}^{+}$uptake was competitively inhibited by excess $\mathrm{Na}^{+}$. The $\mathrm{K}^{+}$contents in leaves, flowers, brown seeds, and black seeds of NaCl-treated $S$. salsa plants were significantly lower, by 37.6, $43.8,55.8$, and $63.3 \%$, respectively, relative to control plants. Interestingly, for $\mathrm{NaCl}$-treated plants, the flowers and brown seeds had significantly higher $\mathrm{K}^{+}$contents than the leaves, while 


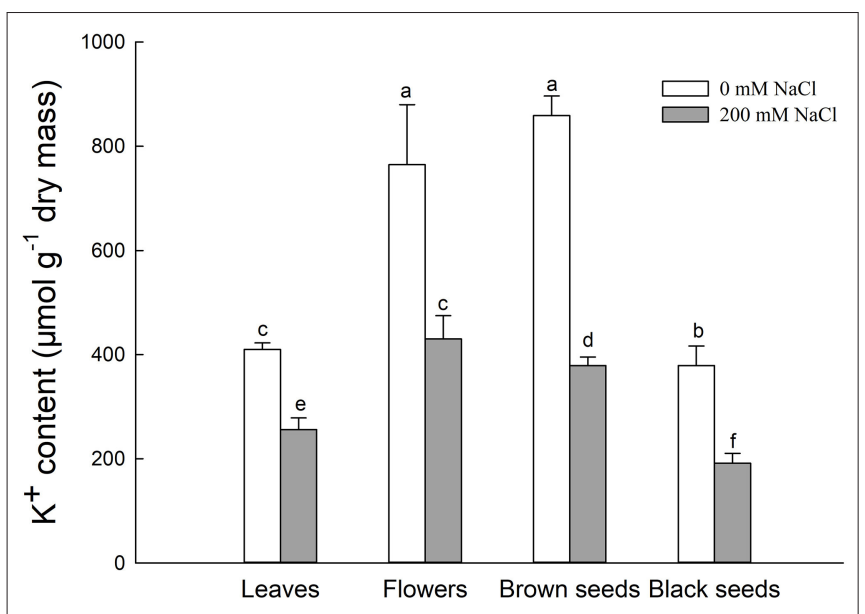

FIGURE 4 | $\mathrm{K}^{+}$content in leaves, flowers, and seeds of second-generation mother Suaeda salsa plants grown on 0 or $200 \mathrm{mM} \mathrm{NaCl}$. Values are presented as means $\pm \operatorname{SD}(n=4)$. Different lower-case letters in the figure indicate significant difference at level of $P<0.05$. the $\mathrm{K}^{+}$contents of the brown and black seeds were 11.8 and $55.5 \%$ lower than that of the flowers (Figure 4). In the control plants, the $\mathrm{K}^{+}$contents of the flowers and brown seeds were also higher than that of the leaves. Although there was no significant difference between the flowers and the brown seeds of the control plants, the black seeds had $31.8 \%$ less $\mathrm{K}^{+}$than the flowers. In both control and $\mathrm{NaCl}$-treated $S$. salsa plants, the brown seeds had much more $\mathrm{K}^{+}$than the black seeds.

\section{The $\mathrm{Na}^{+} / \mathrm{K}^{+}$Ratio in S. salsa Leaves, Flowers, and Seeds}

Given the general increase of $\mathrm{Na}^{+}$content and decrease of $\mathrm{K}^{+}$ content in leaves, flowers, and seeds of $\mathrm{NaCl}$-treated $\mathrm{S}$. salsa plants, we analyzed the $\mathrm{Na}^{+} / \mathrm{K}^{+}$ratio in these organs and found it to be significantly increased in the treated plants. In NaCl-treated $S$. salsa plants, the highest ratio was obtained for leaves, followed by the black seeds; the lowest ratio was observed in the brown seeds (Figure 5). For control plants, the highest $\mathrm{Na}^{+} / \mathrm{K}^{+}$ratio was obtained for leaves, and this was significantly lower than the ratio for the leaves of NaCl-treated plants (Figure 5). There were no significant differences among the $\mathrm{Na}^{+} / \mathrm{K}^{+}$ratios of the flowers and the brown and black seeds of the control plants.

\section{DISCUSSION}

In general, the presence of excess inorganic ions (mainly $\mathrm{Na}^{+}$and $\mathrm{Cl}^{-}$) in saline soils has a toxic effect on plants, producing a hypertonic environment and inhibiting the growth of most non-halophytes (Hosseini et al., 2003; Karimi et al., 2005; Abbasi et al., 2016). As the main organ of higher plant reproduction, seeds are vital for establishing communities in specific environments, especially in ones that are unfavorable. Rapid germination and a high germination rate are important seed characteristics for halophytes to ensure normal plant growth (Tobe et al., 2004; Tlig et al., 2008), and a high salt concentration

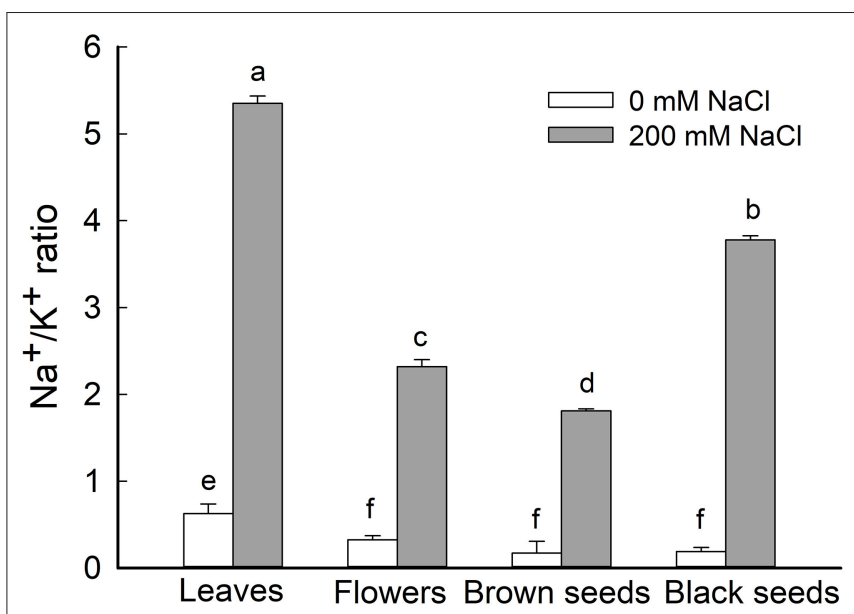

FIGURE 5 | Ratio of $\mathrm{Na}^{+} / \mathrm{K}^{+}$in leaves, flowers, and seeds of second-generation mother Suaeda salsa plants grown on 0 or $200 \mathrm{mM} \mathrm{NaCl}$. Values are presented as means $\pm \mathrm{SD}(n=4)$. Different lower-case letters in the figure indicate significant difference at level of $P<0.05$.

in the environment can delay seed germination (Vleeshouwers et al., 1995). Some halophytes such as Salicornia pacifica (Khan and Hess, 1985), Suaeda physophora (Song et al., 2005), and Suaeda salsa (Guo et al., 2018) sequester large amounts of $\mathrm{Na}^{+}$ions in bracts or the pericarp, and this is important for seed germination and salt tolerance. Large amounts of $\mathrm{K}^{+}$ and $\mathrm{Ca}^{2+}$ accumulated in the hypocotyls of soybean (Glycine max) under high salt stress, and this protected seeds from salt stress at the pre-germination stage (Hosseini et al., 2002). Accumulation of certain ions in the seeds might directly contribute to salt tolerance during seed germination or seedling formation in saline environments. Plants have sophisticated regulatory mechanisms to maintain ionic homeostasis in seeds (Kranner and Colville, 2011).

A saline environment affects both the quality and the development of seeds (Zhou et al., 2016). In Iris hexagona, seeds from plants grown at an elevated salt concentration germinated rapidly and had a higher germination rate than seeds from plants grown at a lower salt concentration (Van Zandt and Mopper, 2004). Our study found that both types of seeds produced by salttreated $S$. salsa plants were bigger than their counterparts from the control plants (Figure 1). The seeds from $\mathrm{NaCl}$-treated plants also had a higher germination rate when seeds were geminated on different concentrations of salt (Figure 2). These results indicate that the presence of some $\mathrm{NaCl}$ in the growing medium was beneficial for seed development in the halophyte $S$. salsa, in turn contributing to improved germination and seedling emergence under saline conditions. This was especially true for the brown seeds from $\mathrm{NaCl}$-treated plants, which had a higher germination rate under high $\mathrm{NaCl}$ conditions, even at $400 \mathrm{mM} \mathrm{NaCl}$, despite having a higher $\mathrm{Na}^{+}$content (Figure 3 ). The ions accumulated in seeds might directly contribute to their salt resistance, especially during germination (Song et al., 2009; Li et al., 2012), and might be beneficial to seedling establishment (Zhou et al., 2014; Guo et al., 2020a). However, the $\mathrm{Na}^{+}$accumulated by the brown seeds 
was not the key factor improving their germination and seedling establishment because the black seeds from $\mathrm{NaCl}$-treated plants had a similar $\mathrm{Na}^{+}$content.

Essential macroelements are vital for plant development. In wheat, plants grown from seeds containing abundant metal ions had enhanced seedling yield and stress resistance (Marschner, 1995). The beneficial effects of metal ions in the soil are reduced by salinity, resulting in metal ion deficiencies and decreased plant quality. In this study, brown $S$. salsa seeds had significantly higher $\mathrm{K}^{+}, \mathrm{Ca}^{2+}, \mathrm{Mg}^{2+}$ contents than black seeds from plants treated with either $0 \mathrm{mM}$ or $200 \mathrm{mM} \mathrm{NaCl}$, although the contents of all three ions were decreased by the $200 \mathrm{mM} \mathrm{NaCl}$ treatment. Additionally, the microelements $\mathrm{Cu}^{2+}, \mathrm{Zn}^{2+}$, and $\mathrm{Fe}^{2+}$ in the brown seeds were also significantly higher than in the black seeds from plants treated with either $0 \mathrm{mM}$ or $200 \mathrm{mM} \mathrm{NaCl}$, and a decreased content was detected when treated with $200 \mathrm{mM} \mathrm{NaCl}$. As in the seeds produced in natural habitats, the content of $\mathrm{K}^{+}$, $\mathrm{Mg}^{2+}$, and $\mathrm{Fe}^{2+}$ in the brown seeds was also significantly higher than that in black seeds (Zhao et al., 2018). The germination rate was also much higher for the brown seeds than for the black seeds from both $\mathrm{NaCl}$-treated and control plants. The germination rate of the brown seeds from treated plants was much higher under high-salinity conditions that that of the black seeds from control (no $\mathrm{NaCl}$ ) plants (Figure 2), indicating that maintaining high levels of $\mathrm{K}^{+}, \mathrm{Ca}^{2+}$, and $\mathrm{Mg}^{2+}$ in the seeds is very important to seed development and seed germination of the halophyte $S$. salsa under saline conditions. However, the detailed mechanism of how elevated levels of $\mathrm{K}^{+}, \mathrm{Ca}^{2+}$, and $\mathrm{Mg}^{2+}$ are maintained in brown seeds of $S$. salsa needs further study.

$\mathrm{K}^{+}$is indispensable for signaling in plant growth and development, and therefore $\mathrm{K}^{+}$concentrations should remain at high levels even under salinity (Wu et al., 2018; Guo et al., 2019; Wang et al., 2019). However, the $\mathrm{K}^{+}$content will decrease due to high concentrations of $\mathrm{Na}^{+}$in the environment and plant tissues. The $\mathrm{K}^{+}$content was significantly lower in dimorphic (black and brown) seeds from treated plants compared with the controls (Table 1). These results were consistent with the $\mathrm{K}^{+}$ content in plants under salt stress ( $\mathrm{Hu}$ et al., 2018). For the dimorphic seeds of $\mathrm{NaCl}$-treated plants, the brown seeds had higher $\mathrm{K}^{+}$contents than the black ones. This was consistent with the high salt tolerance of brown seeds from $\mathrm{NaCl}$-treated plants, indicating that a high $\mathrm{K}^{+}$content, rather than $\mathrm{Na}^{+}$, in plant cells enhanced plant growth and salt tolerance (Liu et al., 2018; Wu et al., 2018; Wang et al., 2019), which was also reflected in the $\mathrm{Na}^{+} / \mathrm{K}^{+}$ratio in the flowers of treated S. salsa plants (Figure 5).

$\mathrm{Zn}$ is a microelement that is involved in salt tolerance in plants by enhancing the activity of antioxidant enzymes and protecting cell membrane integrity (Jan et al., 2017). Interestingly, the $\mathrm{Zn}^{2+}$ cation content was significantly lower in black $S$. salsa seeds from $\mathrm{NaCl}$-treated plants, but significantly higher in the brown seeds compared with control seeds (Table 2). Additionally, the brown seeds from NaCl-treated plants showed higher salt tolerance than the black seeds (Figure 2) from NaCl-treated plants and seeds from control plants (Song et al., 2008, 2009; Guo et al., 2018). Perhaps the high salt tolerance was associated with the increased $\mathrm{Zn}^{2+}$ content in the brown seeds from the NaCl-treated plants. This is similar to results in Arabidopsis thaliana, where lines overexpressing the zinc transporter ZIP29 showed significantly higher salt tolerance than the wild type (Wang et al., 2010). Therefore, some mechanism for efficient $\mathrm{Zn}$ accumulation might be employed in the brown seed of $S$. salsa under salt treatment, which enhances salt tolerance and does not occur in the black seeds from NaCl-treated plants. The difference in the $\mathrm{Zn}^{2+}$ content between the black and brown seeds in $S$. salsa may lead to the different responses to salt in the dimorphic seeds, and thus merits further analysis.

Plants use complicated mechanisms to absorb and transport mineral elements from the soil, and to redistribute these elements in the plant, even in the seeds (Kranner and Colville, 2011). To investigate the pattern of ion accumulation in $S$. salsa plants under saline conditions, we measured the $\mathrm{Na}^{+}$and $\mathrm{K}^{+}$ contents in leaves, flowers, and seeds. The $\mathrm{K}^{+}$content in flowers and brown seeds was significantly higher than that in leaves (Figure 4), but the $\mathrm{K}^{+}$content was lower than in control plants, indicating that more $\mathrm{K}^{+}$was transported into the brown seeds from leaves and flowers. This $\mathrm{K}^{+}$was transported along with a large amount of $\mathrm{Na}^{+}$from leaves to floral organs (Figure 3), thus maintaining a relatively stable $\mathrm{Na}^{+} / \mathrm{K}^{+}$ratio (Figure 5) in the flowers. The $\mathrm{K}^{+}$likely enhanced the salt tolerance of brown seeds that germinated under high salt conditions (Figure 2). Therefore, S. salsa seems to have a mechanism for efficient transport of $\mathrm{K}^{+}$ from the flower to the seed, and shows a positive effect of $\mathrm{K}^{+}$ retention in the seed, despite the high content of $\mathrm{Na}^{+}$in flowers and seeds of the treated $S$. salsa plants. The high $\mathrm{Na}^{+}$content in the leaves and flowers was beneficial to form succulent leaves in S. salsa (Qi et al., 2009) and floral organs (mainly succulent in the petals).

Along with the $\mathrm{K}^{+}$, more anions (such as $\mathrm{Cl}^{-}$and $\mathrm{NO}_{3}^{-}$) would be absorbed to balance the cation accumulation and ensure the growth and development of plants under salinity (Song et al., 2009; Guo et al., 2018). However, the high $\mathrm{Na}^{+}$ and $\mathrm{Cl}^{-}$contents did not inhibit the development of seeds in $S$. salsa treated with $\mathrm{NaCl}$, but rather enhanced seed development; this enhancement was associated with efficient photosynthesis and photosynthetic products accumulation in the reproductive organs (Guo et al., 2020b). The enhancement was also associated with the regulation of plant hormones (Guo et al., 2020c), and the maintenance of $\mathrm{K}^{+}$and $\mathrm{Zn}^{2+}$ content in a certain range to indirectly ensure successful reproduction of $S$. salsa.

In conclusion, the accumulation of cations such as $\mathrm{K}^{+}$and $\mathrm{Zn}^{2+}$, but not $\mathrm{Na}^{+}$, in seeds from NaCl-treated $S$. salsa plants appears to be an adaptive mechanism that helps $S$. salsa survive and reproduce in saline conditions. The $S$. salsa seeds (both black and brown) from salt-treated plants were significantly larger than those from control conditions. Furthermore, the seeds had a higher seed quality and salt tolerance than seeds from plants without $\mathrm{NaCl}$, despite the lower contents of $\mathrm{K}^{+}, \mathrm{Ca}^{2+}$, and $\mathrm{Fe}^{2+}$ in brown seeds. The seed development and seed quality was not affected by the reduced contents of these ions and higher $\mathrm{Na}^{+}$ content. Especially for brown seeds from NaCl-treated plants, the cation accumulation, particularly $\mathrm{Zn}^{2+}$, may enhance seed development and salt tolerance during germination. However, the full confirmation is needed to further analyze. Further research will be required to uncover the detailed mechanism 
of cation accumulation, particularly $\mathrm{K}^{+}$and $\mathrm{Zn}^{2+}$, in brown S. salsa seeds.

\section{DATA AVAILABILITY STATEMENT}

The original contributions presented in the study are included in the article/Supplementary Material, further inquiries can be directed to the corresponding authors.

\section{AUTHOR CONTRIBUTIONS}

JG and BW conceived the original project, designed the experiments, and wrote the article. LL and MD performed most of the experiments. LL and HT performed the statistical analysis. All authors contributed to the article and approved the submitted version.

\section{REFERENCES}

Abbasi, H., Jamil, M., Haq, A., Ali, S., Ahmad, R., Malik, Z., et al. (2016). Salt stress manifestation on plants, mechanism of salt tolerance, and potassium role in alleviating it: a review. Zemdirbyste 103, 229-238. doi: $10.13080 / \mathrm{z}-\mathrm{a} .2016 .103 .030$

Ding, G., Liu, J., Shi, L., and Xu, F. (2010). Plant inomics: a new field in plant nutrition. Plant Nutr. Fertilizer Sci. 16, 479-484. doi: 10.11674/zwyf.2010.0232

Ebrahimi, R., and Bhatla, S. (2012). Ion distribution measured by electron probe $\mathrm{x}$-ray microanalysis in apoplastic and symplastic pathways in root cells in sunflower plants grown in saline medium. J. Biosci. 37, 713-721. doi: 10.1007/s12038-012-9246-y

Flowers, T. J., and Yeo, A. R. (1986). Ion relations of plants under drought and salinity. Funct. Plant Biol. 13, 75-91. doi: 10.1071/PP9860075

Guo, J., Dong, X., Han, G., and Wang, B. (2019). Salt-enhanced reproductive development of Suaeda salsa L. coincided with ion transporter gene upregulation in flowers and increased pollen $\mathrm{K}^{+}$content. Front. Plant Sci. 10:333. doi: 10.3389/fpls.2019.00333

Guo, J., Du, M., Lu, C., and Wang, B. (2020b). NaCl improves reproduction by enhancing starch accumulation in the ovules of the euhalophyte Suaeda salsa. BMC Plant Biol. 20:262. doi: 10.1186/s12870-020-02 468-3

Guo, J., Du, M., Tian, H., and Wang, B. (2020a). Exposure to high salinity during seed development markedly enhances seedling emergence and fitness of the progeny of the extreme halophyte Suaeda salsa. Front. Plant Sci. 11:1291. doi: 10.3389/fpls.2020.01291

Guo, J., Li, Y., Han, G., Song, J., and Wang, B. (2018). NaCl markedly improved the reproductive capacity of the euhalophyte Suaeda salsa. Funct. Plant Biol. 45, 350-361. doi: 10.1071/FP17181

Guo, J., Lu, C., Zhao, F., Gao, S., and Wang, B. (2020c). Improved reproductive growth of euhalophyte Suaeda salsa under salinity is correlated with altered phytohormone biosynthesis and signal transduction. Funct. Plant Biol. 47, 170-183. doi: 10.1071/FP19215

Guo, J., Suo, S., and Wang, B. S. (2015). Sodium chloride improves seed vigour of the euhalophyte Suaeda salsa. Seed Sci. Res. 25, 335-344. doi: 10.1017/S0960258515000239

Hafsi, C., Falleh, H., Saada, M., Ksouri, R., and Abdelly, C. (2017). Potassium deficiency alters growth, photosynthetic performance, secondary metabolites content, and related antioxidant capacity in Sulla carnosa grown under moderate salinity. Plant Physiol. Biochem. 118, 609-617. doi: 10.1016/j.plaphy.2017.08.002

Han, N., Shao, Q., Lu, C. M., and Wang, B. S. (2005). The leaf tonoplast $\mathrm{V}-\mathrm{H}^{+}$-ATPase activity of a $\mathrm{C}_{3}$ halophyte Suaeda salsa is enhanced by salt stress in a Ca-dependent mode. J. Plant Physiol. 162, 267-274. doi: 10.1016/j.jplph.2004.07.016

\section{FUNDING}

This work was supported by the National Natural Science Foundation of China (Grant No. 31770288), the independent innovation and achievement transformation of special major key technical plans of Shandong Province (2017CXGC0313), the Natural Science Research Foundation of Shandong Province (ZR2017MC003), and the Higher Educational Science and Technology Program of Shandong Province (J17KA136).

\section{SUPPLEMENTARY MATERIAL}

The Supplementary Material for this article can be found online at: https://www.frontiersin.org/articles/10.3389/fpls.2020. 602427/full\#supplementary-material

Hosseini, M., Powell, A. A., and Bingham, I. J. (2003). The interaction between salinity stress and seed vigour during germination of soyabean seeds. Seed Sci. Technol. 31, 715-725. doi: 10.15258/sst.2003.31.3.20

Hosseini, M. K., Powell, A. A., and Bingham, I. J. (2002). Comparison of the seed germination and early seedling growth of soybean in saline conditions. Seed Sci. Res. 12, 165-172. doi: 10.1079/SSR2002108

Hu, W., Loka, D. A., Fitzsimons, T. R., Zhou, Z., and Oosterhuis, D. M. (2018). Potassium deficiency limits reproductive success by altering carbohydrate and protein balances in cotton (Gossypium hirsutum L.). Environ. Exp. Bot. 145, 87-94. doi: 10.1016/j.envexpbot.2017.10.024

Hu, Y., Burucs, Z., Tucher, S. V., and Schmidhalter, U. (2007). Shortterm effects of drought and salinity on mineral nutrient distribution along growing leaves of maize seedlings. Environ. Exp. Bot. 60, 268-275. doi: 10.1016/j.envexpbot.2006.11.003

Imbert, E. (2002). Ecological consequences and ontogeny of seed heteromorphism. Perspect. Plant Ecol. 5, 13-36. doi: 10.1078/1433-8319-00021

Jan, A. U., Hadi, F., Midrarullah, Nawaz, M. A., and Rahman, K. (2017). Potassium and zinc increase tolerance to salt stress in wheat (Triticum aestivum L.). Plant Physiol. Biochem. 116, 139-149. doi: 10.1016/j.plaphy.2017.05.008

Karimi, G., Ghorbanli, M., Heidari, H., Nejad, R. K., and Assareh, M. H. (2005). The effects of $\mathrm{NaCl}$ on growth, water relations, osmolytes, and ion content in Kochia prostrata. Biol. Plant. 49, 301-304. doi: 10.1007/s10535-005-1304-y

Kausar, A., and Gull, M. (2019). Influence of salinity stress on the uptake of magnesium, phosphorus, and yield of salt susceptible and tolerant sorghum cultivars (Sorghum bicolor L.). J. Appl. Biol. Biotech. 7, 53-58. doi: 10.7324/JABB.2019.70310

Khan, M. A., and Hess, D. J. W. M. (1985). Elemental distribution in seeds of the halophytes Salicornia pacifica var. utahensis and atriplex canescens. Am. J. Bot. 72, 1672-1675. doi: 10.1002/j.1537-2197.1985.tb08436.x

Kranner, I., and Colville, L. (2011). Metals and seeds: biochemical and molecular implications and their significance for seed germination. Environ. Exp. Bot. 72, 93-105. doi: 10.1016/j.envexpbot.2010.05.005

Kranner, I., Minibayeva, F. V., Beckett, R. P., and Seal, C. E. (2010). What is stress? concepts, definitions, and applications in seed science. New Phytol. 188, 655-673. doi: 10.1111/j.1469-8137.2010.03461.x

Kudla, J., Batistič, O., and Hashimoto, K. (2010). Calcium signals: the lead currency of plant information processing. Plant Cell 22, 541-563. doi: 10.1105/tpc.109.072686

Lahner, B., Gong, J., Mahmoudian, M., Smith, E. L., Abid, K. B., Rogers, E. E., et al. (2003). Genomic scale profiling of nutrient and trace elements in Arabidopsis thaliana. Nat. Biotechnol. 21, 1215-1221. doi: 10.1038/nbt865

Li, X., Liu, Y., Chen, M., Song, Y. P., Song, J., Wang, B. S., et al. (2012). Relationships between ion and chlorophyll accumulation in seeds and adaptation to saline environments in Suaeda salsa populations. Plant Biosyst. 146, 142-149. doi: 10.1080/11263504.2012.727880 
Liu, Q., Liu, R., Ma, Y., and Song, J. (2018). Physiological and molecular evidence for $\mathrm{Na}^{+}$and $\mathrm{Cl}^{-}$exclusion in the roots of two Suaeda salsa populations. Aquat. Bot. 146, 1-7. doi: 10.1016/j.aquabot.2018.01.001

Ma, L., Ye, J., Yang, Y., Lin, H., Yue, L., Luo, J., et al. (2019). The SOS2-SCaBP8 complex generates and fine-tunes an AtANN4-dependent calcium signature under salt stress. Dev. Cell 48, 697-709. doi: 10.1016/j.devcel.2019.02.010

Marschner, H. (1995). Mineral Nutrition of Higher Plants[M]. Boston, MA: Academic Press.

Mori, S., Suzuki, K., Oda, R., Higuchi, K., Maeda, Y., Yoshiba, M., et al. (2011). Characteristics of $\mathrm{Na}^{+}$and $\mathrm{K}^{+}$absorption in Suaeda salsa (L.) Pall. Soil Sci. Plant Nutr. 57, 377-386. doi: 10.1080/00380768.2011.586322

Munns, R., and Tester, M. (2008). Mechanisms of salinity tolerance. Annu. Rev. Plant Biol. 59, 651-681. doi: 10.1146/annurev.arplant.59.032607.092911

Pang, C., Li, K., and Wang, B. (2011). Overexpression of SsCHLAPXs confers protection against oxidative stress induced by high light in transgenic Arabidopsis thaliana. Physiol. Plant. 143, 355-366. doi: 10.1111/j.1399-3054.2011.01515.x

Pang, C., Zhang, S., Gong, Z., and Wang, B. (2005). NaCl treatment markedly enhances $\mathrm{H}_{2} \mathrm{O}_{2}$-scavenging system in leaves of halophyte Suaeda salsa. Physiol. Plant. 125, 490-499. doi: 10.1111/j.1399-3054.2005.00585.x

Qi, C., Chen, M., Song, J., and Wang, B. (2009). Increase in aquaporin activity is involved in leaf succulence of the euhalophyte Suaeda salsa, under salinity. Plant Sci. 176, 200-205. doi: 10.1016/i.plantsci.2008.09.019

Qiu, N., Chen, M., Guo, J., Bao, H., Ma, X., and Wang, B. (2007). Coordinate upregulation of $\mathrm{V}-\mathrm{H}^{+}$-ATPase and vacuolar $\mathrm{Na}^{+} / \mathrm{H}^{+}$antiporter as a response to $\mathrm{NaCl}$ treatment in a $\mathrm{C}_{3}$ halophyte Suaeda salsa. Plant Sci. 172, 1218-1225. doi: 10.1016/j.plantsci.2007.02.013

Salt, D. E., Baxter, I., and Lahner, B. (2008). Ionomics and the study of the plant ionome. Annu. Rev. Plant Biol. 59, 709-733. doi: 10.1146/annurev.arplant.59.032607.092942

Song, J., Chen, M., Feng, G., Jia, Y., Wang, B., and Zhang, F. (2009). Effect of salinity on growth, ion accumulation, and the roles of ions in osmotic adjustment of two populations of Suaeda salsa. Plant Soil 314, 133-141. doi: $10.1007 /$ s11104-008-9712-3

Song, J., Fan, H., Zhao, Y., Jia, Y., Du, X., and Wang, B. (2008). Effect of salinity on germination, seedling emergence, seedling growth, and ion accumulation of a euhalophyte Suaeda salsa in an intertidal zone and on saline inland. Aquat. Bot. 88, 331-337. doi: 10.1016/j.aquabot.2007.11.004

Song, J., Feng, G., Tian, C., and Zhang, F. (2005). Strategies for adaptation of Suaeda physophora, Haloxylon ammodendron, and Haloxylon persicum to a saline environment during seed-germination stage. Ann. Bot. 96, 399-405. doi: $10.1093 / \mathrm{aob} / \mathrm{mci} 196$

Song, J., Shi, W., Liu, R., Xu, Y., Sui, N., Zhou, J., et al. (2017). The role of the seed coat in adaptation of dimorphic seeds of the euhalophyte Suaeda salsa to salinity. Plant Spec. Biol. 32, 107-114. doi: 10.1111/1442-1984. 12132

Song, J., and Wang, B. (2015). Using euhalophytes to understand salt tolerance and to develop saline agriculture: Suaeda salsa as a promising model. Ann. Bot. 115, 541-553. doi: $10.1093 / \mathrm{aob} / \mathrm{mcu} 194$

Song, J., Zhou, J., Zhao, W., Xu, H., Wang, F., Xu, Y., et al. (2016). Effects of salinity and nitrate on production and germination of dimorphic seeds applied both through the mother plant and exogenously during germination in Suaeda salsa. Plant Spec. Biol. 31, 19-28. doi: 10.1111/1442-1984. 12071

Talavera, M., Ortiz, P. L., Arista, M., Berjano, R., and Imbert, E. (2010). Disentangling sources of maternal effects in the heterocarpic species Rumex bucephalophorus. Perspect. Plant Ecol. 12, 295-304. doi: 10.1016/j.ppees.2010.07.002
Tlig, T., Gorai, M., and Neffati, M. (2008). Germination responses of Ddiplotaxis harra to temperature and salinity. Flora 203, 421-428. doi: 10.1016/j.flora.2007.07.002

Tobe, K., Li, X., and Omasa, K. (2004). Effects of five different salts on seed germination and seedling growth of Haloxylon ammodendron (chenopodiaceae). Seed Sci. Res. 14, 345-353. doi: 10.1079/SSR2004188

Ungar, I. A. (1995). Seed Germination and Seed-Bank Ecology in Halophytes. NewYork, NY: Marcel Dekker, 599-628. doi: 10.1201/9780203740071-23

Van Zandt, P. A., and Mopper, S. (2004). The effects of maternal salinity and seed environment on germination and growth in Iris hexagona. Evol. Ecol. Res. $6,813-832$.

Vleeshouwers, L. M., Bouwmeester, H. J., and Karssen, C. M. (1995). Redefining seed dormancy: an attempt to integrate physiology and ecology. J. Ecol. 83, 1031-1037. doi: $10.2307 / 2261184$

Wang, B., Lüttge, U., and Ratajczak, R. (2004). Specific regulation of sod isoforms by $\mathrm{NaCl}$ and osmotic stress in leaves of the $\mathrm{C}_{3}$ halophyte Suaeda salsa $\mathrm{L}$. J. Plant Physiol. 161, 285-293. doi: 10.1078/0176-1617-01123

Wang, L., Dong, M., and Huang, Z. (2010). Review of research on seed heteromorphism and its ecological significance. Chin. J. Plant Ecol. 34, 578-590. doi: 10.3773/j.issn.1005-264x.2010.05.012

Wang, W., Xu, Y., Chen, T. X., Xing, L., Xu, K., Ji, D., et al. (2019). Regulatory mechanisms underlying the maintenance of homeostasis in Pyropia haitanensis under hypersaline stress conditions. Sci. Total Environ. 662, 168-179. doi: 10.1016/j.scitotenv.2019.01.214

Wu, H., Liu, X., You, L., Zhang, L., Zhou, D., Feng, J., et al. (2012). Effects of salinity on metabolic profiles, gene expressions, and antioxidant enzymes in halophyte Suaeda salsa. J. Plant Growth Regul. 31, 332-341. doi: 10.1007/s00344-011-9244-6

Wu, H., Zhang, X., Giraldo, J. P., and Shabala, S. (2018). It is not all about sodium: revealing tissue specificity and signalling roles of potassium in plant responses to salt stress. Plant Soil 431, 1-17. doi: 10.1007/s11104-018-3770-y

Yang, M. F., Song, J., and Wang, B. S. (2010). Organ-specific responses of vacuolar $\mathrm{H}^{+}$-ATPase in the shoots and roots of $\mathrm{C}_{3}$ halophyte Suaeda salsa to $\mathrm{NaCl} . J$. Integr. Plant Biol. 52, 308-314. doi: 10.1111/j.1744-7909.2010.00895.x

Yang, Z., Wang, C., Xue, Y., Liu, X., Chen, S., Song, C., et al. (2019). Calciumactivated 14-3-3 proteins as a molecular switch in salt stress tolerance. Nat. Commun. 10:1199. doi: 10.1038/s41467-019-09181-2

Zhao, Y., Yang, Y., Song, Y., Li, Q., and Song, J. (2018). Analysis of storage compounds and inorganic ions in dimorphic seeds of euhalophyte suaeda salsa. Plant Physiol. Bioch. 130, 511-516. doi: 10.1016/j.plaphy.2018.08.003

Zhou, J., Fu, T. T., Sui, N., Guo, J. R., Feng, G., Fan, J. L., et al. (2016). The role of salinity in seed maturation of the euhalophyte Suaeda salsa. Plant Biosyst. 150, 83-90. doi: 10.1080/11263504.2014.976294

Zhou, J. C., Zhao, W. W., Yin, C. H., Song, J., Wang, B. S., Fand, J. L., et al. (2014). The role of cotyledons in the establishment of Suaeda physophora seedlings. Plant Biosyst. 148, 584-590. doi: 10.1080/11263504.2013.788574

Conflict of Interest: The authors declare that the research was conducted in the absence of any commercial or financial relationships that could be construed as a potential conflict of interest.

Copyright $\odot 2020 \mathrm{Guo}, \mathrm{Liu}, \mathrm{Du}$, Tian and Wang. This is an open-access article distributed under the terms of the Creative Commons Attribution License (CC BY). The use, distribution or reproduction in other forums is permitted, provided the original author(s) and the copyright owner(s) are credited and that the original publication in this journal is cited, in accordance with accepted academic practice. No use, distribution or reproduction is permitted which does not comply with these terms. 